\title{
SPRAWOZDANIE Z OGÓLNOPOLSKIEJ KONFERENCJI: POSTAWY DECYDENTÓW WSPÓLNOT POLITYCZNYCH I KOŚCIELNYCH WOBEC WOLNOŚCI OBYWATELSKICH ORAZ WYZNANIOWYCH MIESZKAŃCÓW WE WCZESNONOWOŻYTNEJ EUROPIE. RÓŻNICE I PODOBIEŃSTWA DOŚWIADCZEŃ I RP I INNYCH KRAJÓW, (INSTYTUT NAUK HISTORYCZNYCH UKSW 27 LISTOPADA 2015 R.)
}

27 listopada 2015 roku na Wydziale Nauk Historycznych i Społecznych Uniwersytetu Kardynała Stefana Wyszyńskiego w Warszawie odbyła się konferencja ogólnopolska „Postawy decydentów wspólnot politycznych i kościelnych wobec wolności obywatelskich oraz wyznaniowych mieszkańców we wczesnonowożytnej Europie. Różnice i podobieństwa doświadczeń I RP i innych krajów”. Konferencję poprowadził i otworzył dr hab. Dariusz Milewski, zastępca Dyrektora INH UKSW.

Pierwszą sesję zapoczątkował referat prof. dr. hab. Janusza Ekesa: Między ,'WOLNOŚCIA DO..." a ,'WOLNOŚCIĄ OD...", czyli o wczesno-nowożytnej sytuacji pojęć”. Autor na początku wyjaśnił pojęcia „wolności do” i „wolności od”. Odniósł się do czasów starożytnych, by wytłumaczyć pojęcia woli i chęci. Opisał, z czym pojęcie wolności utożsamiał Machiavelli.

Kolejny referat wygłosił prof. dr hab. Zbigniew Bania z UKSW: Nowe interpretacje formalno-ideowe włoskiej architektury przełomu XV/XVI wieku. Prelegent wyjaśnił, jak zmieniała się w czasie interpretacja budowli rzymskiego Koloseum. Na przykładzie kolegiaty w Klimontowie przedstawił inspiracje budowlane zapożyczone z Bazyliki św. Piotra w Rzymie.

Jako trzecia wystąpiła dr Katarzyna Kozak z Uniwersytetu Przyrodniczo-Humanistycznego w Siedlcach z referatem Wizja wolności wedtug Pio Rossi w dyskursie politycznym wczesnonowożytnych Włoch. Omówione tutaj zostało życie i poglądy głównego bohatera na tle sytuacji politycznej ówczesnej Italii. Autorka przestawiła także inne pojęcia wolności reprezentowane np. przez Bernardino Telesio.

Wystąpieniem kończącym pierwszą część konferencji był referat dr. hab. Piotra Tafiłowskiego z Uniwersytetu Marii Curie-Skodowskiej w Lublinie pod tytułem Absolutyzm i legitymizacja władzy w Mediolanie pod rządami Ludovica Sforzy. Prelegent omówił dokładnie okres rządów Ludovico Sforzy, nie pomijając niechlubnych decyzji władcy (zamach stanu). Po przedstawionym referacie nastąpiła dyskusja, a później przerwa. 
Kolejną część konferencji rozpoczął dr Valentin Constantinov z mołdawskiej Akademii Nauk w Kiszyniowie (Academia de Ştiinţe a Moldovei) referatem Bojarzy mołdawscy $i$ ich prawa obywatelskie - między prawem ziemskim a polskim modelem szlacheckim. Prelegent ukazał funkcjonowanie prawa w państwie mołdawskim i wyjaśnił stosunki panujące między hospodarem a poddaną mu szlachtą.

Kolejnym prelegentem był prof. dr hab. Włodzimierz Marciniak z Akademii Ignatianum w Krakowie z referatem Postawy pierwszych Romanowów wobec wolności obywatelskich oraz wyznaniowych mieszkańców państwa moskiewskiego. Na początku zostało przedstawione rozróżnienie pojęć wola i swoboda przez ówczesnych Rosjan. Później prelegent ukazał, jak wygladała władza panującego, nie pomijając problemów związanych z jej legitymizacją.

Następny referat przedstawiła dr Teresa Bałuk-Ulewiczowa z Uniwersytetu Jagiellońskiego: Wawrzyniec Goślicki, ustrój mieszany i mieszane uczucia o tzw. złotej wolności szlacheckiej. Autorka omówiła tutaj dzieło Goślickiego pod tytułem De optimo senatore, podkreślając, w jaki sposób autor przedstawiał wolność w swoim dziele.

Ostatnim wystąpieniem drugiej części konferencji był referat dr. Radosława Lolo z Akademii Humanistycznej w Pułtusku pod tytułem Zagłada chrześcijaństwa w Europie Nowożytnej? Autor oparł się w swoim wystąpieniu na książce Marka Greengrassa Christendom Destroyed: Europe 1517-1648, poddając ją krytyce. Prelegent przedstawił, w jaki sposób katolicy byli ukazywani przez ówczesnych ludzi na przykład na podstawie drzeworytów. Później miała miesjce dyskusja i przerwa.

Ostatnią część konferenji poprowadził ks. prof. dr hab. Wojciech Zawadzki. Jako pierwszy referat zaprezentował prof. dr hab. Dariusz Makiłła z Wyższej Szkoły Finansów i Zarządzania w Warszawie: Landesherr i jego Landeskirche. Stosunki religijne w Prusach Ksiązęcych $w X V I-X V I I$ w. Autor opisał, jak wyglądały sprawy kościelne w państwie pruskim i jaki wpływ na nie mieli władcy począwszy od Albrechta Hohenzollerna.

Następnie referat wygłosił dr hab. Sławomir Kościelak z Uniwersytetu Gdańskiego: Rada miejsca wobec wolności wyznania katolickiego w Gdańsku w drugiej połowie XVI i pierwszej połowie XVII wieku. Prelegent przedstawił bardzo złą pozycję katolików w tym mieście, na co złożyły się przywileje dane mu przez Zygmunta Augusta, Henryka Walezego i Stefana Batorego.

Kolejny referat, pod tytułem Proces marginalizacji katolików w protestanckim Elblagu na przełomie XVI i XVII wieku, wygłosił ks. prof. dr hab. Wojciech Zawadzki z UKSW. Autor w swoim wystapieniu ukazał, w jaki sposób prawa katolików w mieście były łamane i pomniejszane. Profesor Zawadzki podkreślił, iż katolicy w tym mieście mieli najmniejsze prawa religijne spośród innych największych miast pruskich (Gdańsk, Toruń).

Przedostatni referat wygłosił mgr Adrian Leszek z UKSW: Arianie Arciszewscy - postawa rodu względem wiary oraz stużby Rzeczpospolitej w pierwszej połowie XVII w. Autor skupił się na dokładnym przedstawieniu życia i wyznania dwóch członków rodu Arciszewskich: Eliasza młodszego i Krzysztofa.

Ostatnim prelegentem był prof. dr hab. Jan Dzięgielewski z UKSW: Czy projekty ,procesu Konfederacji Warszawskiej"' z przełomu XVI/XVII w. umocnityby pokój wyznaniowy w Rzeczpospolitej? Autor wytłumaczył, czym była Konfederacja Warszawska i przedstawił sytaucję polityczną ówczesnej RP, która nie pozwalała na uchwalenie procesów do tejże Konfederacji.

Ks. prof. dr hab. Wojciech Zawadzki poprowadził dyskusję i zamknął całą konferencję. 